Routledge Studies in Modern History

28 The Chronicle of a People's War: The Military and Strategic History of the Cambodian Civil War, 1979-1991

Boraden Nhem

29 The Assyrian Genocide Cultural and Political Legacies

Edited by Hannibal Travis

30 The Russo-Japanese War and its Shaping of the Twentieth Century Frank Jacob

31 Understanding the City through its Margins

Pluridisciplinary Perspectives from Case Studies in Africa, Asia and the Middle East

Edited by André Chappatte, Ulrike Freitag and Nora Lafi

32 The Style and Mythology of Socialism: Socialist Idealism, 1871-1914 Stefan Arvidsson

33 Capitalism and Religion in World History

Purification and Progress

Carl Mosk

34 Michael Collins and the Financing of Violent Political Struggle Nicholas Ridley

35 Censuses and Census Takers

A Global History

Gunnar Thorvaldsen

36 America and the Postwar World: Remaking International Society, 1945-1956

David Mayers

For more information about this series, please visit: www.routledge.com/ history/series/MODHIST

\section{International Organizations and the Media in the Nineteenth and Twentieth Centuries}

Exorbitant Expectations

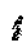

Edited by Jonas Brendebach, Martin Herzer, and Heidi Tworek 
Routledge is an imprint of the Taylor o Francis Group, an informa business

(c) 2018 selection and editorial matter, Jonas Brendebach, Martin

Herzer and Heidi Tworek; individual chapters, the contributors

The right of Jonas Brendebach, Martin Herzer and Heidi Tworek

to be identified as the authors of the editorial material, and of the

authors for their individual chapters, has been asserted in accordance with sections 77 and 78 of the Copyright, Designs and Patents Act 1988

All rights reserved. No part of this book may be reprinted or

reproduced or utilized in any form or by any electronic, mechanical, or other means, now known or hereafter invented, including photocopying and recording, or in any information storage or retrieval system, without permission in writing from the publishers.

Trademark notice: Product or corporate names may be trademarks or registered trademarks, and are used only for identification and explanation without intent to infringe.

British Library Cataloguing-in-Publication Data

A catalogue record for this book is available from the British Library

Library of Congress Cataloging-in-Publication Data

A catalog record for this book has been requested

ISBN: 978-1-138-30308-9 (hbk)

ISBN: 978-1-351-20643-3 (ebk)

Typeset in Sabon

by Apex CoVantage, LLC 


\section{The public image of the Universal Postal Union in the Anglophone world, 1874-1949}

\author{
Richard R. John
}

The history of the Universal Postal Union, opined English social commentator H. G. Wells in 1940, was "surely something that should be made part of the compulsory education of every statesman and publicist." Sadly, however it remained largely unknown. "Never in my life," Wells added, had he met a "professional politician who knows anything whatever or wanted to know anything about it."1

Wells's assessment highlighted a curious truth. Close students of public affairs have long regarded the Postal Union-the customary name for this organization before the Second World War-not only as one of the oldest and most effective of the world's international organizations, but also as one of most obscure.

This essay explores this paradox. It contends that the obscurity of the Postal Union was, to a significant degree, intentional. Postal Union administrators understood that their operational success rested in large part on their ability to convince the public that, unlike generals and diplomats, they were dispassionate experts who lacked a political agenda. Had contemporaries come to regard their deliberations as partisan, rather than as neutral and objective, they risked embroilment in Great Power politics. And should this happen, they would lose the autonomy that they had attained as technical professionals. ${ }^{2}$

In one sense the agency's low profile is surprising. For an organization established to coordinate international communications, the Postal Union devoted few resources to communicating internationally. In another sense the agency's reticence was strategic. By staying out of the headlines, the Postal Union steered clear of the unpredictable media-driven controversies that could easily have undermined its legitimacy.

To show how the Postal Union communicated with the public, the essay surveys the organization's public image in the Anglophone world during its formative era, which began in 1863 and closed in 1949. The focus is on Great Britain, the United States, and three of Britain's largest settler colonies: Canada, Australia, and New Zealand. My primary source base is the periodical press and ephemeral items such as postcards, souvenir envelopes, and postage stamps.
This period witnessed the eclipse of colonialism and the ascendancy of the territorially based nation-state as the main unit of international relations, a shift hastened by two devastating world wars that would lead to the establishment of a new international organization - the United Nations-to mitigate the conflicts inflamed by Great Power rivalries. ${ }^{3}$ It also marked the rise of the Postal Union as a standard-setting agency. The kinds of standards that Postal Union administrators devised focused on the form of the mail rather than its substance. Had they expanded their ambit to embrace the content of the information and goods that postal patrons sent, they would almost certainly have found themselves entangled in highly charged ethical and moral controversies with their member countries.'Instead, they confined themselves to content-neutral technical protocols. At their most ambitious, they envisioned the creation of a borderless world, an almost utopian goal in an age when the territorially bounded nation was on the march.

It would be revealing to conduct parallel studies of similar sources for other parts of the world. Yet these five Anglophone countries make for a suggestive case study not only because they accounted for a large percentage of the world's postal traffic, but also because they had long been the home of promoters convinced of the humanitarian-promise of technical improvements in international communications. Faith in the emancipatory potential of improved communications was in no sense an Anglophone monopoly. Indeed, in certain ways, it was part of a broader, "civilizational" project with eloquent advocates in France, Germany, and many other parts of the world. ${ }^{4}$ Yet, in large part because of the power and reach of the Anglophone press, Anglophone ideas were disproportionately influential. It is, thus, especially telling that even here the Postal Union's achievements remained so little known.

$$
* * *
$$

The beginnings of the Postal Union go back to 1863 , when an international conference of postal administrators met in Paris at the suggestion of U.S. postmaster general Montgomery Blair. ${ }^{5}$ The 1863 conference did not lead immediately to the formation of a permanent bureaucracy. Yet it did establish precedents that would hasten the creation in 1874 of a selfperpetuating organization, the "General Postal Union." Four years later, this agency rebranded itself as the Universal Postal Union, its name today. The Postal Union has always been headquartered in Berne; since 1948, it has been affiliated with the United Nations as a "Specialized Agency." In its early years, the Swiss government administered the Postal Union's permanent office, which was known as the "International Bureau"; for many years, its staff would consist of little more than a director, who before 1966 was always a prominent $S$ wiss public figure, and a handful of administrative assistants. ${ }^{6}$ 
Prior to the commercialization of the Internet in the $1990 \mathrm{~s}$, the mail was, for the vast majority of the world's peoples, the primary means of international communications. For this reason alone, the history of the Postal Union is worth pondering. The telegraph, with minor exceptions, was never configured as a mass medium, while international telephony would remain prohibitively expensive for all but the few until well after the Second World War. "The true "Victorian telegraph" was neither the telegraph, nor the telephone, but the mail. ${ }^{8}$ And for more than a century and a half, it had devolved on the Postal Union to establish and maintain the protocols necessary to coordinate the circulation of the mail around the world.

Journalists often praised the Postal Union for the capaciousness of its mission and the effectiveness of its administration. "Of all the co-operative schemes that have been set in motion by mankind," asserted one American journalist in 1895, in an article in a small-town newspaper in rural Georgia, "it is probable that the world's postal system, everything considered, is the most satisfactory in its operations." The world boasted 150 international organizations, reported the influential British journalist William T. Stead in 1910, of which 112 had permanent bureaucracies: "The most perfect and highly evolved of all these international organizations is the Universal Postal Union." 10 The Postal Union was one of the world's only organizations that had realized the longstanding dream of successfully instituting an effective body of international law, observed a Baltimore journalist in $1924 .{ }^{11}$ Of all the world's international organizations, declared one Australian journalist in 1929, there were none that "affects so closely the maintenance of everyday communication between nation and nation," making the Postal Union a "cornerstone of modern civilization." 12

These tributes to the Postal Union highlight the magnitude of its achievement. Yet it would be a mistake to assume that these accomplishments were common knowledge. Though the Postal Union had hastened a "revolution in the constitution of the society of nations," declared English social commentator Leonard Woolf in 1916, it had done so not in the bright glare of publicity, but in "placid obscurity." 13 Revolutions are often noisy and highly visible. In the case of international postal communications, however, a revolution succeeded and almost no one noticed.

Three conclusions emerge from my survey of the public image of the Postal Union in the Anglophone world during its formative era. First, Postal Union administrators devoted few resources to explaining their operations to the public. Second, the Postal Union found its way into the press primarily during the relatively brief intervals when its delegates assembled in an international congress. Third, some of the most revealing representations of the Postal Union were pictorial, and can be found on postcards, souvenir envelopes, and postage stamps. While historians often ignore this kind of source material, these items circulated by the millions, providing us with a window into popular conventions concerning the relationship between the Postal Union, governmental institutions, and the global flow of information. ${ }^{14}$

$$
* * *
$$

The public image of the Postal Union was shaped only partly by the organization itself. With the exception of L'Union Postale, a trilingual monthly magazine written by and for postal insiders, Postal Union administrators devoted few resources to informing the public about how the organization worked and why it mattered. And on those rare occasions when they did try to reach out to the public-for example, to promote a new service or to tackle the perennial problem of ill-addressed letters-they almost always relied on the already established national postal administrations to get their message across. ${ }^{15}$ When journalists discovered the hand of the Postal Union in some post-office-related issue, they were often surprised.

The protocols devised by the Postal Union to standardize the world's postage stamps are a case in point. From the moment of its founding, Postal Union administrators tried to fix the color of postage stamps, a goal that became mandatory at the 1897 Washington Postal Union congress. Henceforth, the most commonly used postage stamps were to be color-coded: green for postcards, red for domestic letter-mail, and blue for international mail. This mandate was the exception that proved the rule. Though the Postal Union had, in fact, shaped the design of one of the world's most ubiquitous items, its precise role in this process remained so obscure that journalists repeatedly found themselves obliged to remind their readers just how it worked. ${ }^{16}$

The disinclination of Postal Union administrators to sing their own praises cannot be attributed to the absence of a relevant precedent. Had they wished to publicize the benefits of long-distance communications, they could easily have drawn on the flood of words and images circulated in the preceding decades by British and American cheap-postage lobbyists. Led by the American blacksmith-turned-postal agitator Elihu Burritt, these promoters urged British and American lawmakers to standardize transatlantic postal rates by instituting "ocean penny postage."17 Typical of the publicity that they generated was a widely circulated engraving printed in 1850 by the Dundee, Scotland, job printer James Valentine. This engraving, which had almost certainly been inspired by Burritt's ocean penny postage campaign, featured a constellation of evocative words and images that included a transoceanic handshake, an imaginary postage stamp featuring the messenger god Hermes, and the optimistic banner "Britain! From thee the world expects an ocean penny postage to make her children one fraternity" (Figure 3.1).

To underscore the practicality of the sought-after rate reduction, the engraving featured three of the recently perfected modes of transportation upon which postal administrators had come to rely: a canal boat, a railroad, 


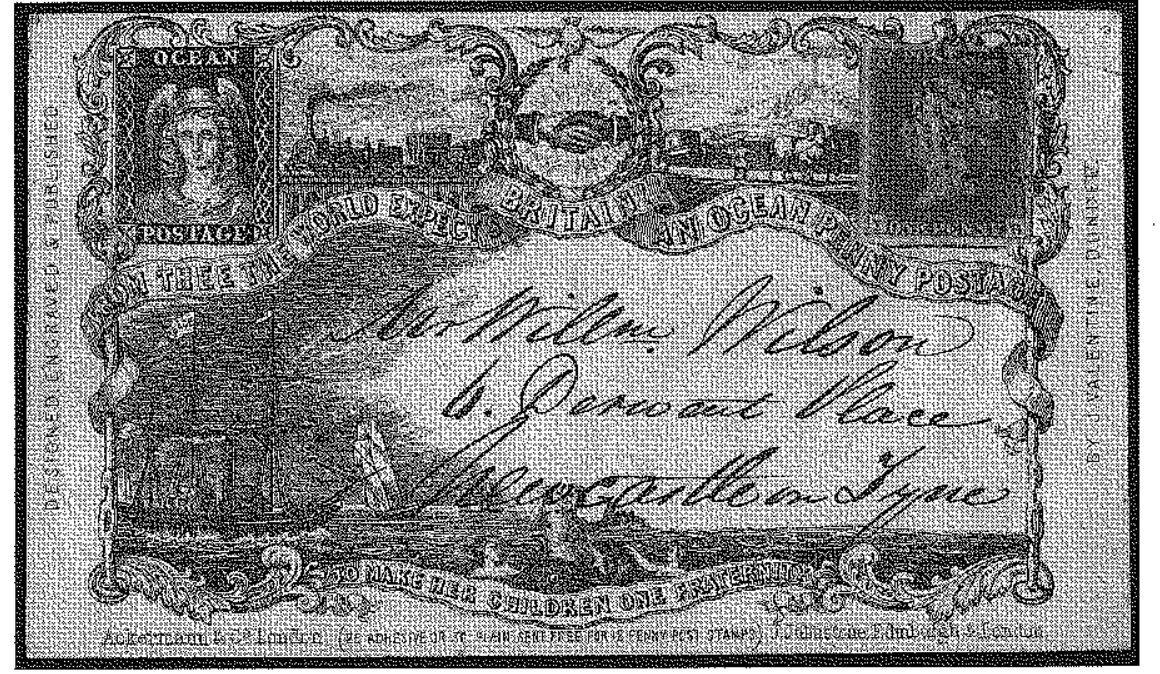

Figure 3.1 British engraved envelope (1850) hailing the humanitarian benefits of low-cost "ocean penny postage."

Source: Robert Dalton Harris

a steamship. The handshake and messenger god were familiar symbols; new modes of transportation were not. In 1850, the first modern canal in Great Britain was only ninety years old; the first British railroad had been in operation for a mere two decades; and the first transatlantic mail steamship had gone into operation as recently as 1839 .

The first generation of Postal Union administrators deliberately rejected appeals of this kind. The most characteristic image to emerge from the 1863 Paris postal conference was neither a classical deity, nor a symbol of international harmony such as a handshake or a dove, nor even a recently adopted mode of postal transportation. Rather, it was a photographic montage, or "mosaique," featuring portraits of 24 men associated with the conference. The primary inspiration for this montage did not originate within the organization. Rather, it was the brainchild of the flamboyant Paris commercial photographer André-Adolphe-Eugène Disdéri, the inventor of the carte de visite..$^{18}$

Photographs often tell stories and Disdéri's montage was no exception. Pride of place went to French postmaster general Edouard Vandal, the head of the French delegation and the president of the conference, and U.S. postmaster general Montgomery Blair, the government administrator who had issued the initial call (but who was not a delegate and did not attend the conference itself). At the very center of the ensemble was the British delegate, Frederick Hill. Hill himself had made few constructive contributions to the
Paris conference: in fact, he had worked behind the scenes to limit its ambit. Yet, as the brother of the visionary British postal administrator Rowland Hill, he was a living link to the single most famous reformer in postal history. The cornerstone of Rowland Hill's reform had been the establishment in the United Kingdom of a low and uniform countrywide letter-postage rate known as "penny postage," an innovation that spurred the issuance of the world's first postage stamp in 1840 . The delegates to the 1863 postal conferenceincluding its most dogged promoter, the American congressman-turned-postal administrator John A. Kasson-recognized the relevance for international communications of Rowland Hill's innovation. By foregrounding Frederick Hill, they channeled the memory of his brother, Rowland. ${ }^{19}$ i

The absence of metaphorical imagery from the 1863 Paris postal conference helps to explain the challenge a later generation of American illustrators confronted when called upon to depict visually an event that journalists often regarded as an American triumph. One solution was to fall back on a likeness of Kasson. ${ }^{20}$ While flattering to American sensibilities, this solution begged many questions, including the indisputable role in the later history of the Postal Union of the Prussian postal administrator Heinrich von Stephan.

Little changed following the formal establishment of the Postal Union in 1874. For a quarter century, the organization met and devised regulations. With the exception of their published proceedings, the increasingly elaborate photographic montages, and the commemorative medals struck as mementos for congress delegates, these meetings left little in the way of a public record. ${ }^{21}$

One exception occurred in 1900, when the Postal Union convened a special congress in Berne to commemorate the organization's first quarter century, or "jubilee." 22 To celebrate this anniversary; delegates set up a competition to commission a prominent sculptor to create a permanent monument for the organization. ${ }^{23}$

At the same time, and in a similar spirit, the Swiss Post Office commissioned the renowned art nouveau illustrator Eugène Grasset to design a postage stamp heralding the Postal Union's anniversary. Grasset's design featured a classical goddess who with one hand clutched a telegraph pole festooned with a Swiss flag while the other scattered letters around the world. What precisely was Grasset celebrating? Though the telegraph pole held aloft the banner "Jubilé de l'Union Postal Universelle," the main focus of Grasset's design was not the Postal Union but the Swiss Post Office. The inclusion of the telegraph pole in Grasset's design underscores the point. The Swiss telegraph at this time was owned and operated by the Swiss Post Office, yet the telegraph had nothing to do with the Postal Union, since international telegraphic communications fell under the jurisdiction not of the Postal Union, but of the International Telegraph Union.

Of the many ephemeral items spawned by the Postal Union jubilee, perhaps the most stunning was a multicolor art nouveau postcard designed by Berne artist Rudolph Münger. The postcard featured five statuesque women 
whose physiognomy and dress linked each of them with a different continent: Europe, Asia, Australia, Africa, and the Americas. Like so much of the commemorative imagery that originated in Europe during this period, its theme was unabashedly Eurocentric. In the middle of the tableau was a globe upon which the woman symbolizing Europe had placed a document proclaiming the establishment of the Postal Union in 1874, while the rest of the world looked on. ${ }^{24}$ The message could not have been clearer: Europe led and the rest of the world followed (Figure 3.2).

Munger's postcard was a commercial venture commissioned by a Berne publisher to capitalize on the Postal Union anniversary. It was not, that is, an official Postal Union publication. Yet it drew heavily on the iconography of a very similar-and equally Eurocentric-invitation that Munger had devised earlier that year for the Postal Union's 25 th anniversary celebration. This invitation had been designed at the behest of, and in close conjunction with, the director of the Postal Union's International Bureau, Eugène Ruffy. The design of the postcard and the invitation were so similar that the postcard can be fairly regarded as a characteristic example of the public image that the Postal Union's staff wished to project. ${ }^{25}$

The Postal Union monument was dedicated in 1909. Among its backers was the German Postal Union delegation, which had come up with the idea, and the Swiss federal council, which oversaw the international competition
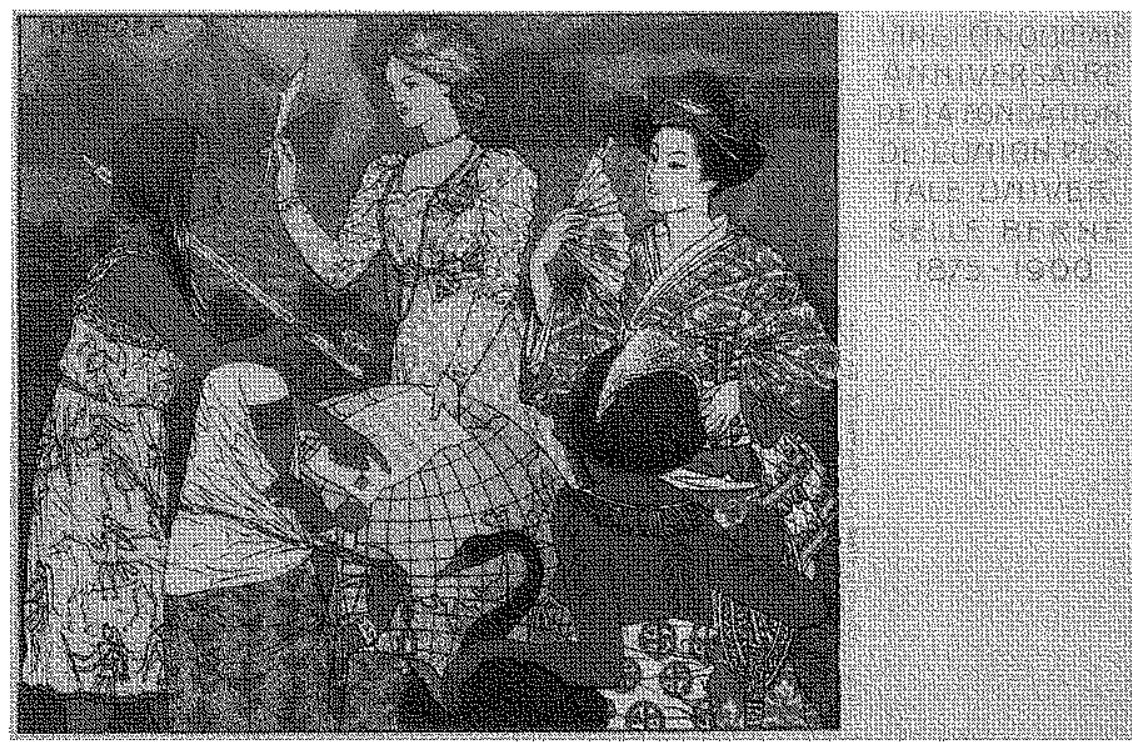

Figure 3.2 Swiss art nouveau lithograph (c.1900) highlighting the pivotal role of Europe (the female figure with a quill pen in her hand) in the founding of the Postal Union.

Source: author's collection to choose a winning design ${ }^{26}$ Over one hundred sculptors submitted entries, each of which was examined by a jury of "celebrated artists" from ten different European countries. Following a winnowing process that reduced the number of entrants to six, French sculptor René de Saint-Marceaux received the commission. ${ }^{27}$ Saint-Marceaux's final design included two main elements: a globe around which swirled five letter-bearing genii, each representing a different continent; and a statue of Berna, the guardian of the city in which the Postal Union was headquartered. Saint-Marceaux's credentials for this assignment extended beyond his artistic prowess: a self-proclaimed utopian visionary, he championed a single world coinage, a single "universal postage," and a single world language..$^{28}$

Unveiled in 1909, Saint-Marceaux's monument was often reproduced on postcards, and, beginning with the 75 th anniversary of the Postal Union in 1949, on souvenir envelopes and postage stamps. The first postage stamp to feature the monument was issued by Guatemala in 1946; interestingly, it appeared in a series that commemorated not the Postal Union, but the issuance of the first postage stamp by Great Britain in $1840 .{ }^{29}$ Beginning in 1949, the monument would appear on dozens of postage stamps issued specifically to commemorate the Postal Union. The first rendering of the monument on the cover of L'Union Postale occurred in 1951; sixteen years later it would become the Universal Postal Union's official logo, which it has remained ever since. ${ }^{30}$ Some post-1949 renderings of the monument included both of the major elements of Saint-Marceaux's design-that is, both the globe-encircling genii and the statue of Berna. Yet as time passed Berna tended to recede: she is, for example, nowhere to be found on the official logo of the Universal Postal Union today.

The backstage maneuvering behind the commissioning of the Berne monument provides a window into the competing agendas of Postal Union delegates. The initial proposal, accompanied by an offer of financial support, came from the German postmaster general, Victor Adolph von Podbielski, who had succeeded Heinrich von Stephan in this position following von Stephan's death in 1897. ${ }^{31}$ Podbielski intended the monument to commemorate the 25th anniversary of the Postal Union, which he dated to 1874, and, in particular, to the pivotal role in its founding not only of Stephan, but also of the less-well-known German postal administrators who had been lobbying for improved international communications ever since the AustroGerman postal union of $1850 . .^{32}$

Podbielski's linkage of Germany with the Postal Union owed much to the rising tide of German nationalism. Having recently defeated France in the Franco-Prussian War, Germany was determined to assume a more prominent role on the international stage. By highlighting Stephan's role in the founding of the Postal Union, Podbielski elevated his country's profile. Yet he also gave honor where honor was due. Stephan had played a key role in 1874, and following his death in 1897 his colleagues had hoped that his achievements might be remembered. 
46 Richard R. John

Podbielski's proposal had the effect, which was presumably his intention, of rewriting the history of the Postal Union. Henceforth, historical accounts of its founding downplayed not only the 1863 Paris postal conference, at which the United States delegation had played such a conspicuous role, but also the 1878 Paris postal congress, at which the Postal Union had changed its name from the prosaic "general" to the more evocative "universal." The name change reflected the organization's mission. Postal Union mandates were not conventional bilateral or multilateral treaties between independent countries, but, rather, innovative transborder agreements to which every member had given consent. ${ }^{33}$

Postal Union administrators modified Podbielski's proposal in two ways. First, they specified that the monument would be erected in Berne, closing off the possibility that it might end up in another city, such as Stephan's Berlin. Second, they enlisted the Swiss federal council to coordinate the competition..$^{34}$ In so doing, they parried Great Power rivalries while highlighting the connection between the Postal Union, the Swiss government, and the city of Berne.

Saint-Marceaux called the final version of his sculpture "Autour du monde," or "Around the World." Colloquially it would come to be known simply as the "Postal Union Monument" (Figure 3.3). A "picture in granite and bronze," as one contemporary put it, it celebrated both an organization with a space-transcending mission and a place-bound city. ${ }^{35}$ The Berne connection was emphasized on the monument's right side, which

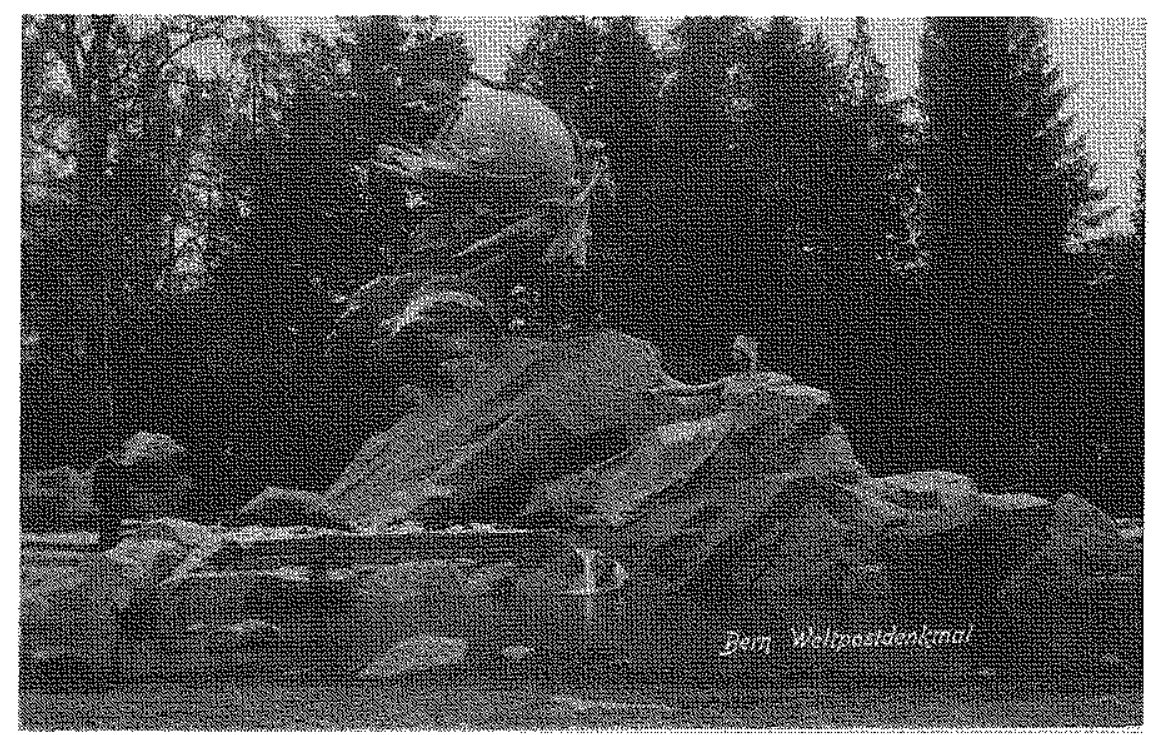

Figure 3.3 Swiss postcard of Rene de Saint-Marceaux's 1909 Postal Union monument. Source: Robert Dalton Harris featured Berna, a "noble, majestic woman" who symbolized the city. Clad in a long flowing robe-which, as prudish critics did not fail to remark, left one her breasts uncovered-Berna proudly wore a crenelated crown that symbolized the city's independence and civic pride while resting her right hand on Berne's "escutcheon," or coat of arms, which included a bear (Figure 3.4). ${ }^{36}$

Berna was not part of the original maquette that Saint-Marceaux submitted to the competition organizers. ${ }^{37}$ How and why she was added is a conundrum. Very possibly, her inclusion followed a request from Swiss authorities to explicitly link the organization with its host city. The Swiss connection was important for a second reason. In the decades following the political convulsions of 1848 , the Swiss government renounced its militaristic past for a new identity as Europe's preeminent honest broker. By hosting international organizations such as the Postal Union and the International Telegraph Union, it burnished its reputation for neutrality, impartiality, and fairness. ${ }^{38}$ The final design of the Postal Union monument celebrated not only the mandate of a standard-setting organization, but also the reach of the Swiss government's "soft power" campaign.

The Postal Union's mission was illustrated on the monument's left side, which featured a globe around which five genii danced with envelopes in their outstretched hands. ${ }^{39}$ "Floating gracefully through space," observed one journalist, "they seem to be passing letters from one to another." ${ }^{40}$ Each

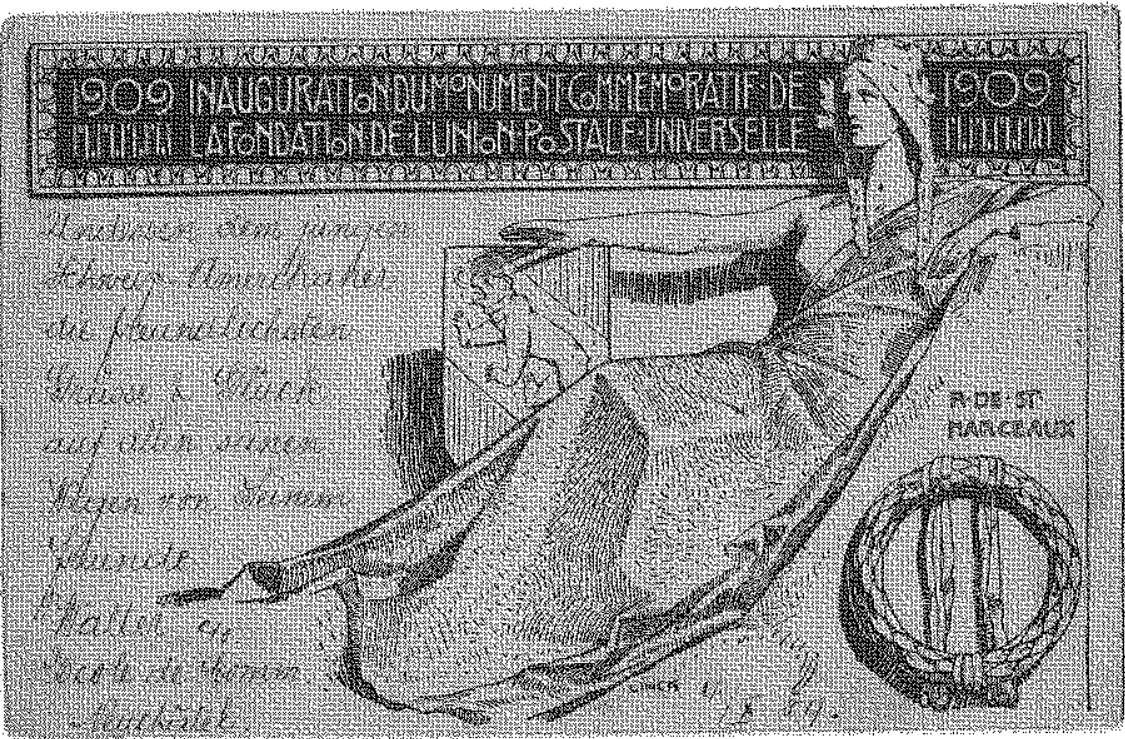

Figure 3.4 Swiss postcard of Berna-one of the two principal elements of the Posta Union monument.

Source: author's collection 
genii represented a different continent-Europe, Africa, Asia, Australia, and the Americas-rendered in a stereotypical way, a convention reminiscent of Münger's art nouveau postcard commemorating the Postal Union's 25th anniversary. Though the genii representing Europe is given pride of place at the front of the composition, she is no longer depicted as bequeathing the Postal Union to the world. Saint-Marceaux's Eurocentrism is less obvious. With the exception of Asia, who is mostly concealed at the back of the sculpture, Europe is the only one of the five genii to be fully clothed-a subtle hint that the continent represented a high stage of civilization. ${ }^{41}$

The iconography of Saint-Marceaux's monument was purely allegorical. Absent was any allusion to the role of postal pioneers Blair or Stephan or the modes of transportation upon which the Postal Union relied. Nowhere could there be found a railroad or steamship, even though each was indispensable to international communications, while no one would have interpreted the genii as a stand-in for an airplane, a mode of transportation that remained in its infancy in 1909.

The public response to Saint-Marceaux's composition was highly positive. Art experts praised its "most unique conception." 42 Specialists in international law hailed it for rendering manifest the mission of an organization that until now had operated primarily behind-the-scenes. Of all of the world's international organizations, declared one legal expert, the Postal Union "most intimately affects the everyday life of people the world over." With the commissioning of this "artistic monument," the world had finally become "conscious of its influence." 43 The monument celebrated "internationalism," reflected American educator Ellen Hayes. Such an internationalism, Hayes predicted-she wrote amidst the turmoil of the First World War-would be "varied, powerful, and enduring," the byproduct not of "diplomatic papers" but of the "open determination" of the "plain people themselves." ${ }^{44}$ The "beneficent influence" of the Postal Union-the "Parliament of the Post"-editorialized a British journalist shortly after the Armistice, had been translated into a three-dimensional form with the "handsome" monument in Berne. ${ }^{45}$

Postal Union administrators were equally impressed. The unveiling of Saint-Marceaux's monument, declared the editors of L'Union Postale, was a notable event in the history not only of the international post, but also of the world: "It was, in fact, the first time that nearly all the Governments of the earth united to erect at their common expense an artistic monument in honor of a great international work, created with the intent of drawing the peoples of the globe into closer bonds of sympathy and friendship and of facilitating among them material, intellectual, and moral relationships." 46 The monument's symbolic flaunting of national borders was especially apt, mused Postal Union administrator Eugène Ruffy, in a tribute to Saint-Marceaux: "With your globe revolving in space, and your chain of graceful forms advancing even more rapidly in their airy flight, you have well depicted the activity of the universal post." 47
The inclusivity that Saint-Marceaux's monument symbolized was a pillar of the Postal Union's mission. Bellicose nations such as Britain and France presided over rival globe-spanning empires; the Postal Union treated the world as a single borderless territory. The structure of the Postal Union reinforced this distinction. Unlike most international organizations, its membership was not confined to sovereign nations. Colonial possessions such as British India had a vote, as did emerging nations such as Turkey. ${ }^{48}$ In recognition of the Postal Union's principled commitment to inclusivity, and in marked contrast to prevailing norms in international relations, administrators referred to its members not as états (states), but as pays (countries). ${ }^{49}$ The very first article of the convention establishing the Postal Union in 1874, explained British postal administrator and Postal Union delegate F.H. Williamson in 1930 , bound its signatories to treat the world as "one single territory" for the "purpose of mutual exchange of correspondence." For "postal purposes," Williamson elaborated, this meant that "international frontiers entirely disappear." The "freedom of transit" was not merely an "idle aspiration." Rather, it was the "keystone of the whole postal edifice," since it enabled every Postal Union member to take advantage of every means of postal transportation that had been put into service by every member country. ${ }^{50}$

To circulate the mail without regard for national boundaries inevitably raised questions of equity. Mail transportation was expensive and it was hard to persuade postal administrators that the burden was fairly shared. The temptation to rely on postal revenue as a form of general taxation also remained. Inevitably, some countries believed that they were paying too much. By doing what they could to keep these issues out of the press, Postal Union administrators minimized their disruptive potential. By eschewing publicity, they augmented their reputation as authoritative professionals. Given the vital role of international mail as "one of the mainsprings of modern civilization," Williamson explained, it was high praise indeed that the organization remained so little known. After all, the circulation of the mail across national borders presupposed the existence not only of an "extremely complicated machinery" to transport the mail, but also of a "comprehensive and detailed organization" to coordinate its circulation. It was "not unfair to say," Williamson concluded, "that the International Postal Service works in an obscurity that is the direct result of its efficiency," an assessment with which Postal Union administrators would have readily concurred. ${ }^{51}$

$$
* * *
$$

Between 1874 and 1929, the Postal Union convened in Anglophone countries only twice. The first Anglophone congress took place in Washington, in 1897; the second in London in 1929.52 Press coverage of the Washington congress consisted primarily of anecdotal vignettes of the workings of a mysterious organization about which journalists assumed the public knew 
50 Richard R. John

next to nothing. The following passage from a February 1897 article in a Wisconsin newspaper was characteristic. Though the journalist reminded his readers that the upcoming Washington congress would almost certainly be one of the "most important" international meetings ever held in the United States, he took it for granted that there were "probably very few persons outside of those actually connected with the postal service who are aware of the existence of the Universal Postal Union, and probably fewer still know anything of its object and history, and the important bearing it has upon the postal affairs of the entire world." 53

American press coverage of the Washington congress emphasized its cosmopolitanism. Americans were not accustomed to playing such a prominent role in international affairs; to fill their readers in; journalists felt obliged to spell out even the most basic details. "They'll Talk French," ran the attentiongrabbing header that one Georgia editor appended to a news agency dispatch. ${ }^{54}$ The delegates' garb was a particular object of fascination. Many of the attendees were decked out in "full court costume," reported one Milwaukee newspaper, "their breasts bespangled with glittering insignia and enameled orders." The "oriental" delegates were particularly "picturesque" with their "flowing silken robes." ${ }^{55}$ Never far from the surface was a thinly veiled undercurrent of concern. Would the U.S. government offer Postal Union delegates the same level of hospitality that they had received at their earlier congresses in Berne, Paris, Lisbon, and Vienna? ${ }^{56}$ Though American postal authorities were "anxious to avoid any unnecessary outlay or any extraordinary or undue display," one journalist conceded, they remained "exceedingly desirous" that the "hospitality of the Republic" should "not suffer by comparison" with the monarchies of Europe..$^{57}$

In describing the congress, journalists reached for superlatives. As a "parliament of man" and "federation of the world," declared one Boston reporter, quoting the English poet Alfred Lord Tennyson, the Washington meeting would "probably have no equal in importance during the rest of the century." 58 The congress was probably the "most representative gathering of all the civilized nations of the earth that has ever assembled," gushed another, adding that it was a matter of "profound pride" for Americans that the "idea creating this union originated with us." $" 59$ Letter writing was the only form of "literary production" accessible to the "great mass" of the world's peoples, observed the Minneapolis Journal shortly after the congress ended, and the Postal Union was "stimulating the demand for internationalismthe effectuation of a stronger bond between the nations to bring about a stronger realization of human brotherhood and the possibility of union in diversity." 60 The Postal Union has "done more to advance civilization generally than any other social or commercial improvement of the present generation," affirmed the Seattle Post-Intelligencer, adding, with a patriotic flourish, that, as the convener of the 1863 Paris postal convention, the United States was "largely entitled to the credit of taking the initiative and pointing out the way to other nations." 61
Journalistic accounts of the Washington congress almost entirely overlooked the substantive issues the delegates discussed. Prominent among them was the refusal of the congress to endorse the proposal of Canadian postmaster general William Mulock to lower the basic international letterpostage rate and the failure of the United States to follow the Postal Union's lead and establish a domestic parcel post.

Mulock's proposal was part of an elaborate campaign that he had been waging for some time to convince the British Parliament to lower Canada's domestic letter-postage rate from three cents to two cents, a 33 percent decrease. At this time, Canadian domestic postal rates were set not in Ottawa, but in London. Should the Postal Union lower the international rate to two cents, Mulock reasoned, Parliament would have no choice but to also lower the Canadian domestic postal rate, since it would be highly anomalous for a Canadian to pay more to mail a letter from Toronto to Montreal than from Toronto to London. The Postal Union refused to budge, but Parliament obliged. At Mulock's urging, it approved the imperial rate reduction following a July 1898 meeting of a British-Empire-only postal convention in London. The adoption of this lower, two-cent imperial rate was widely touted in the press as a practical realization of the long campaign for "imperial penny postage," since two Canadian cents were roughly equivalent to one English penny.

Shortly thereafter, and almost certainly as Mulock had anticipated, the British Parliament voted to reduce the Canadian domestic postal rate from three to two cents. Though Mulock had failed to obtain an international rate reduction from the Postal Union, he had used the forum to pressure Parliament into enacting the domestic rate reduction he sought. ${ }^{62}$ Having played the Postal Union's transborder inclusivity off the British Parliament's imperial particularism, Mulock found in the latter the key to success. ${ }^{63}$

Mulock's triumph furnished the impetus for one of the few distinctive icons to emerge, if indirectly, from the Washington congress. This icon, Mulock's brainchild, took the form of a large, multicolored two-cent postage stamp that the Canadian post office issued shortly after the British Parliament approved the imperial rate reduction in December 1898. "We Hold a Vaster Empire than Has Been," the stamp boldly proclaimed, quoting a passage from the "Song of Empire" written by Sir Lewis Morris to commemorate the fiftieth anniversary of Queen Victoria's reign in 1887. To underscore Canada's enthusiastic embrace of Britain's imperial mission, the stamp featured a Mercator projection of the world's continents that colored imperial red those portions of the globe that belonged to the British Empire. The stamp celebrated not the inclusivity of the Postal Union, which, in Washington, had let Mulock down. Rather, it elevated to a global plane the particularism of the British Empire, from which he had obtained the sought-after rate reduction. In addition, and not incidentally, it advertised the centrality of Canada to the British Empire, whose size the Mercator projection serendipitously magnified. The successful launch a few years later of 


\section{Richard R. John}

a Vancouver-New Zealand underwater cable, the final link in the "All-Red" cable network linking Britain with its empire, was yet another example of the propensity of imperial administrators to privilege the particularism of imperial preference over the inclusivity of a borderless world.

Mulock's conflation of universality with imperial preference was by no means unique. When, for example, the New Zealand post office issued a postage stamp trumpeting "universal postage" in 1901, the universality it celebrated was not that of the Postal Union, but of "imperial penny postage." For Postal Union administrators, the particularism of the British was a badge of reproach: for New Zealand postal administrators, in contrast, the British Empire was the most inclusive collectivity to which they could plausibly aspire to belong.

Nothing comparable to the Canadian rate reduction was forthcoming from the United States. The U.S. Post Office Department did not commemorate the Washington Postal Union congress with a special postage stamp, a custom that would only later become conventional, though it did present congress delegates with "specimen" sheets of general-issue U.S. postage stamps. ${ }^{64}$ While handsome, neither these sheets nor any of the other ephemera that the congress generated could match the visual appeal of the multicolored chromolithographic trade card that the New York City postmaster and his staff had issued several years earlier as a New Year's greeting for their Postal Union "colleagues," very possibly in conjunction with the U.S. Post Office Department's exhibit at the World's Columbian Exposition in Chicago. ${ }^{65}$

While Mulock succeeded in Parliament, U.S.-based cheap transportation lobbyists failed to transform the Washington Postal Union congress into a springboard for a domestic parcel post. The United States in 1897 remained one of the few economically advanced countries that had yet to expand its postal facilities to include the transportation of parcels weighing more than four pounds. Opposition to a domestic parcel post was determined and well organized. Thousands of protectionist-minded wholesalers not implausibly regarded parcel post as the death-knell of their livelihoods. The anomalous position of the U.S. Post Office Department regarding parcel delivery was evident to Postal Union delegates. The Postal Union had established protocols for an international parcel post as far back as 1880; in the following year, the British Post Office would establish a parcel post for the United Kingdom. In the United States, in contrast-and notwithstanding the Postal Progress League's multiyear pro-parcel post lobbying campaign-Congress would not establish a domestic parcel post until 1913.66

Little wonder, then, that on the eve of the 1906 Postal Union congress in Rome, the first to be convened after the Washington congress of 1897 , journalists lambasted the U.S. Post Office Department for its foot-dragging. The "principal advantages" that had been anticipated through the "advanced liberality" of parcel delivery, observed one journalist, had been adopted in the United States only "grudgingly and sparingly." 67 As a consequence,
The Universal Postal Union, 1874-1949 53

another complained, the United States lagged "far behind the rest of the world in a matter that most intimately concerns the welfare of the people." That Congress would facilitate the circulation of overseas parcels within the territorial confines of the United States was considered unlikely, on account of the opposition of business groups to foreign competition. An "international parcels-post" had been often proposed, the journalist elaborated, yet it had been invariably rejected, since it met with a "strong protest" from American manufacturers and merchants. Should the Post Office Department adopt Postal Union standards, they feared quite understandably that this would give foreign competitors a "powerful advantage" by enabling them to mail packages of goods up to a "considerable weight" thoughout the country's vast interior at rates "considerably cheaper" than could their American counterpart. ${ }^{68}$

The failure of parcel post lobbyists in the United States to parlay the Washington Postal Union congress into a domestic parcel post, like the success of Mulock's campaign to lower the basic letter rate in Canada, are but two examples of the Postal Union's entanglement with country-specific special interests. Yet one feature of these contretemps was atypical. Unlike the vast majority of the issues that came before the Postal Union, each found their way into the press.

Press coverage, however, did not necessarily translate into an upsurge in public concern. Letter-postage rates in 1897 were sufficiently low to blunt the appeal of a revival of the 1840 s campaign for cheap ocean postage, while the post-1897 U.S. parcel post debate focused almost entirely on domestic considerations. Indeed, it is only recently that historians have come to realize that the U.S. parcel post debate had an international dimension. ${ }^{69} \mathrm{Had}$ the press covered the Postal Union congress more closely, it would have been easier for contemporaries to grasp that the ramifications of the parcel post issue extended beyond the nation's borders. Yet press coverage remained so superficial that it was the rare journalist who took the trouble to make the connection.

The journalistic response to the 1929 London Postal Union Congress was little different. Though the meeting occurred in one of the world's most cosmopolitan cities, press coverage was mostly preoccupied with ancillary matters that had little bearing on its deliberations. This was true even though the congress received respectful attention from the London Times, which on its opening day featured a detailed essay by F.H. Williamson on the practical workings of the "Universal Post." 70 The limited press coverage of the London congress owed something to the fact that, as was customary, its delib erations were closed to the public. Yet even had Postal Union organizers thrown open their doors, a problem remained. Unlike the 1919 Paris Peace Conference, the 1929 Postal Union congress was "invariably monolingual" all of its proceedings took part in French, with no English translation. ${ }^{71}$ Even the Prince of Wales addressed the congress's 200 delegates in French, a fact that was sufficiently unusual that it was duly noted in the Times. ${ }^{72}$ 
Linguistic barriers were by no means the only reason the London congress received such limited coverage. An even more intractable obstacle was the tension on display in London between two contrasting visions of the emerg ing world order: the particularism of the British Empire versus the inclusivity of the Postal Union.

A case in point was the nomenclature the British used to describe the standard-setting body. The official name of Postal Union in 1929 was-as it had been since 1878-the Universal Postal Union, the name by which the organization, often shortened to its acronym UPU, is typically referred to today. In 1929, however, the word "universal" was omitted not only by British government administrators but also by the British journalists who covered the congress for the press.

Why the British preferred "Postal Union" over "Universal Postal Union" is an interesting question. Aesthetic considerations no doubt played a part: the name "Universal Postal Union" was long and awkward at a time when acronyms were rarely used. No less important was geopolitical calculation. Not until the 75th anniversary of the Postal Union in 1949 would British government administrators come to recognize how useful Postal Union inclusivity could be in promoting British interests at home and overseas. It was at this time, and not before, that the phrase "Universal Postal Union" would become the preferred name for the organization in the Anglophone press.

The tension between particularism and inclusivity was evident in the design of an innovative genre of postage stamps that the British Post Office issued to allegorize the London congress. By 1929 it had become customary for postal administrators in the country in which the Postal Union congress met to issue postage stamps to focus public attention on the organization. Known as "commemoratives," these stamps were intended to fix in the public imagination a specific individual, institution, idea, or image. ${ }^{73}$ Time-specific, they were, as Williamson helpfully explained, a "temporary general issue" that the post office issued for a brief interval as a substitute for the "ordinary stamps." 74 In many countries, including Britain, a Postal Union congress was one of the first specific events that a postal administration commemorated with a special stamp or stamp series. Only once before in the 89-year period since the issuance of the first postage stamp in 1840 , for example, had the British Post Office issued a postage stamp on a timespecific theme. ${ }^{75}$

The 1929 British Postal Union commemoratives consisted of five postage stamps that the post office issued on 10 May 1929, the opening day of the congress. All five bore the phrase "Postal Union Congress London 1929." Interestingly, with the exception of the phrase "Postal Union Congress," none of the stamps included any imagery linking them with the Postal Union. In fact, and with the exception of the $2 \frac{1}{2} \mathrm{~d}$ stamp, which had been intended specifically for international mail, their symbolism was unequivocally imperial. As it happens, the $2 \frac{1}{2} \mathrm{~d}$ stamp was the first in British history not to incorporate a royal crown into its design, a fact that was duly noted in the press. ${ }^{76}$ In all likelihood, the absence of Postal Union imagery troubled few congress delegates. From their point of view, it mattered less that the British government had missed an opportunity to publicize the Postal Union, than that they could take back home a handsome souvenir.

The imperial connection was prominently foregrounded in the $£ 1$ Postal Union stamp, which featured an elaborate engraving of St. George slaying the dragon, a metaphorical allusion to the martial prowess of the British Empire, and also to the nobility of its reigning monarch, whose name also happened to be George (Figure 3.5).

The profusion of particularistic imagery in a stamp series that ostensibly celebrated an organization with an inclusive mission was by no means atypical. British illustrators had relied on similar symbols to commemorate the London meeting of the International Telegraph Union in 1903, as had Rudolph Münger in the postcard he designed to celebrate the 25th anniversary of the Postal Union in $1900 .{ }^{77}$ Even so, the paucity of non-imperial

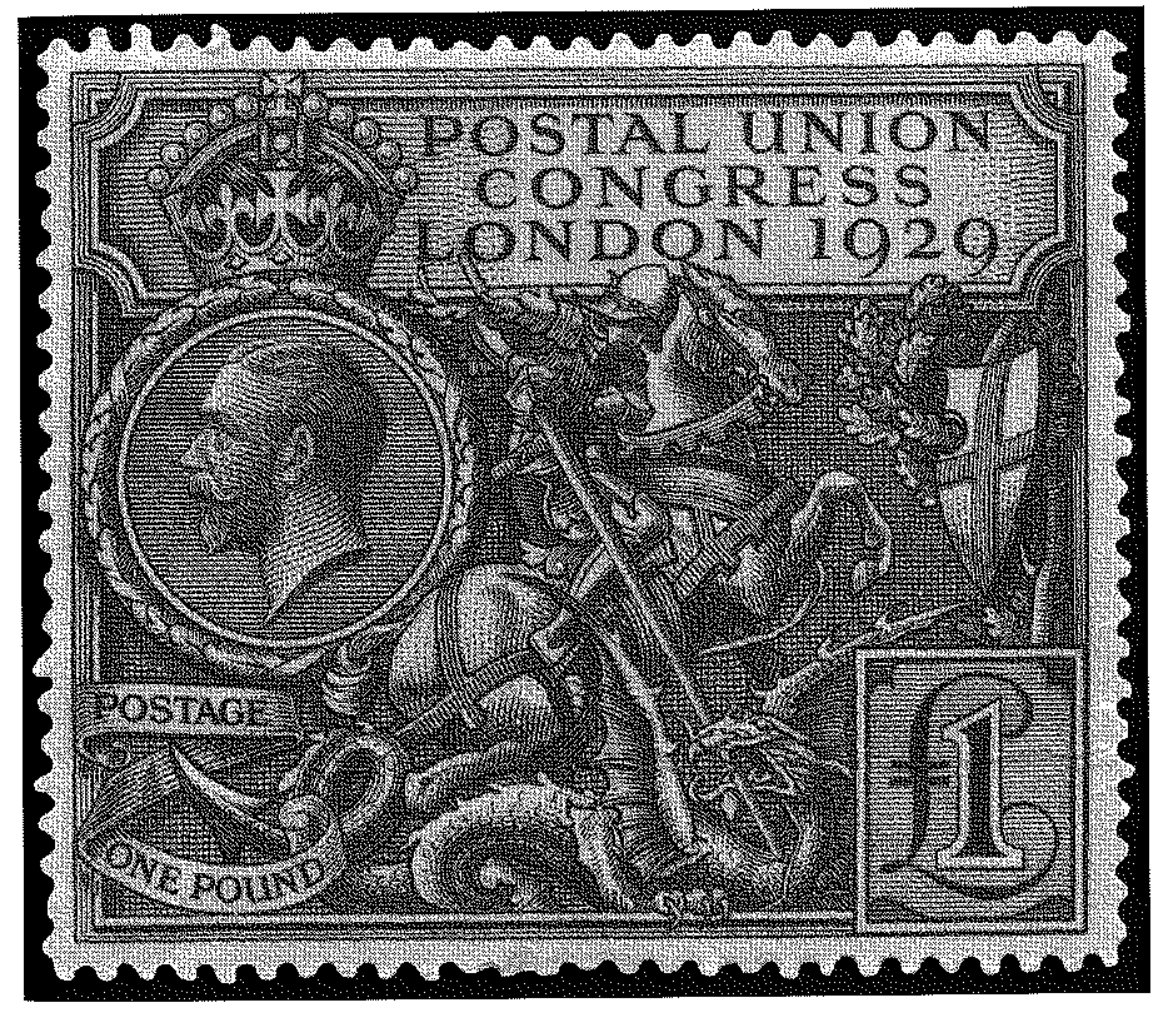

Figure 3.5 High-denomination British postage stamp commemorating the London Postal Union Congress.

Source: Postal Museum, London 
imagery in the five British Postal Union postage stamps underscores the relative invisibility of the Postal Union's mission even when it had convened in the capital of one of the world's most enthusiastic proponents of international communications.

Why the British Post Office issued the $£ 1$ commemorative remains something of a mystery. It was rumored in the press that postal administrators may have wished to increase the value of the stamp set, which they gave out as souvenirs to congress delegates. Alternatively, or so critics charged, they may have looked to the revenue that its sale could have been expected to generate to offset the cost of the congress. ${ }^{78}$ Though the stamp was unquestionably a "remarkable piece of engraving," one Australian journalist observed, it served no "legitimate postal purpose," since it corresponded to no existing postal rate, and had been apparently issued merely to lighten the wallets of those stamp collectors who felt obliged to buy it so that they could fill in a blank space in their album. ${ }^{79}$

The stamp's design raised further questions. The $£ 1$ stamp was the work of Harold Nelson, a prolific "black and white" artist best known as a book illustrator. Nelson was a highly versatile draftsman who was comfortable working in styles that ranged from pre-Raphaelite and Arts and Crafts to art nouveau. Had the Post Office wished Nelson to design a postage stamp that symbolized the achievement of the Postal Union, he was perfectly capable of doing so. Yet the British Post Office Department settled, instead, on a mythological motif-St. George slaying the dragon-that was emphatically imperial.

The irrelevance of imperial imagery to the mission of the Postal Union would not have been lost on postal administrators. As it happens, the stamp was closely modeled on a rejected mock-up for a commemorative that Nelson had prepared five years before for an exposition celebrating the British Empire. Postal officials found Nelson's mock-up unduly arcane: in its place, they selected a more accessible design that combined a roaring lion and a rising sun. ${ }^{80}$ Yet the rejected design had not been forgotten, and, in 1929, Nelson's St. George and the Dragon would be repurposed for the highest-denomination stamp in the Postal Union series.

Alternative options existed. Among the rejected proposals for the $£ 1$ stamp was a handsome design by female illustrator E. M. Jackman that featured modern modes of postal transportation: airplanes, a steamship, and a railroad (Figure 3.6).$^{81}$ Why the British Post Office passed over Jackman's design is a matter of speculation. What can be observed is that, in rejecting it, the British Post Office missed an opportunity to identify the Postal Union with a technocratic vision of modernity, a project that would not advance significantly until it would be embraced by the United States after the Second World War.

The paucity of Postal Union-specific symbolism persisted through the 1930s. When, for example, the Canadian government issued a postage stamp to commemorate the 1933 Ottawa meeting of the Postal Union's

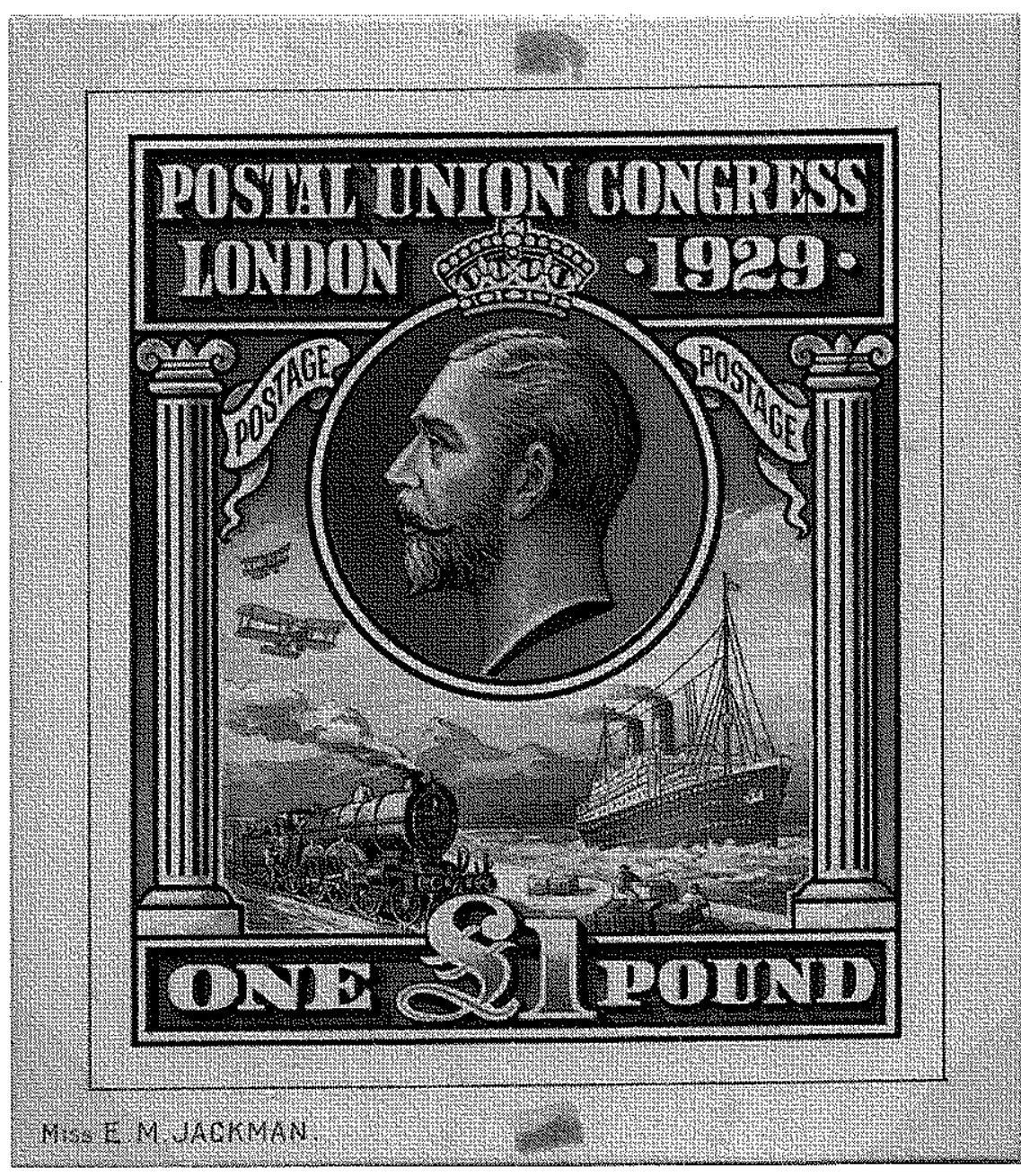

Figure 3.6 Unadopted design for a high-denomination postage stamp for the London Postal Union Congress.

Source: Postal Museum, London

executive committee, its design featured a panoramic view of Canada's principal seat of government, Ottawa's Parliament Hill, an image with no obvious relationship to the Postal Union. When, similarly, the British Post Office in 1937 commissioned graphic designer MacDonald Gill to prepare a wall map depicting mail steamship routes, Gill focused not on the entire world's steamship network-in the inclusive tradition of the Postal Unionbut, rather, on those steamship routes that happened to be under British control. Like Mulock's 1898 Canadian commemorative, Gill's map colored 
Britain's imperial possessions in red. To explain why Britain had proved so successful, Gill appended to it a chronological survey of technical advances in maritime transportation in the past millennium. The British Empire, or so Gill implied, rested on an unassailable foundation of material progress. ${ }^{82}$ No comparable maps of the international postal network circulated in the Anglophone press during the 1930s. Like Mulock's philatelic tribute to the British Empire, Gill's mail steamship map depicted the world through an avowedly imperial lens.

$$
* * *
$$

The Second World War, the rise of airpower, anti-colonialism, and the establishment of the United Nations all transformed the public image of the Postal Union. This transformation had two main features. First, it shifted the main focus of Postal Union imagery from particularism to inclusivity. Second, it furnished the occasion for the popularization of a new design aesthetic that took its inspiration from the future rather than the past.

Both of these themes can be illustrated by considering the public image of the Postal Union featured on postage stamps and souvenir envelopes issued to celebrate its 75 th anniversary in 1949. The Postal Union had recommended at its 1947 Paris meeting that member countries commemorate this milestone by issuing special postage stamps, and many responded. ${ }^{83}$ Britain, the United States, and 84 administrative units of the Commonwealth issued postage stamps. Many countries, including Australia, issued stamps with a unique design. In addition, 64 Commonwealth members issued a fourstamp "omnibus" series designed by the Crown Agency, an intra-imperial clearing house.

Chronological milestones are arbitrary divisions and the Postal Union anniversary was no exception. Its significance lay neither in the longevity of the organization nor in any specific innovation in postal policy. The key, rather, was its timing. The Second World War had decisively tilted the global balance of power away from Britain, Germany, and France and toward the United States. Among the defining features of this new world order was the establishment in 1945 of the United Nations; the affiliation of the Postal Union with the United Nations in 1948; and the legal reconstitution of the British Empire in April 1949 as the Commonwealth. ${ }^{84}$

The new priorities of the British government were reflected in the stamps the British post office issued to commemorate the anniversary. Though each included the ubiquitous monarch's profile and royal crown, none were as flamboyantly imperial as Harold Nelson's $1929 £ 1$ London Postal Union commemorative. Instead, they lauded the Postal Union, which they now dignified with its full name, as an icon of modernity. In 1929 the British government had linked the Postal Union with the British Empire; now it hailed the Postal Union's 75th anniversary as an opportunity to celebrate one of the bonds that united the Commonwealth. Technical advances in communications, British administrators gambled, could help undergird a new, less brazenly triumphalist kind of imperial federation.

Each stamp design mingled in a distinctive way the traditional and the modern. The 1 shilling stamp combined a traditional post horn with a modern rendering of the globe, while the $6 \mathrm{~d}$ stamp depicted a classical deity in a fashionable art deco style, with flowing hair, outstretched arms, and a globeframing eight-point compass. To be sure, none of the stamps were as avantgarde as one of the designs the post office ultimately rejected: a winged art deco postage stamp whirling around a stylized globe (Figure 3.7 ). ${ }^{85}$ Yet none were as blatantly anti-modern as a rejected design that paired the reigning monarch with Hermes, the classical messenger god. ${ }^{86}$ t

The future-oriented comingling of past and present was perhaps best symbolized by the inclusion on the $3 \mathrm{~d}$ issue of an art deco rendering of the Postal Union monument (Figure 3.8). Though modernist in sensibility, the design was faithful to Saint-Marceaux's final conception, featuring both Berna and the five globe-encircling genii. While Berna was clearly delineated, the genii dominated the composition, a harbinger of things to come.

The $3 \mathrm{~d}$ stamp marked a new departure in Postal Union symbolism. While the Postal Union monument had been depicted before this time on postcards and other similar kinds of ephemera, before 1949 it had only once found its way onto a postage stamp. After 1949, spurred at least in part by the enormous prestige of British precedent, stylized renderings of the monument would find their way on to the postage stamps of many countries in Europe, the Commonwealth, and beyond. In many of these renderings, the

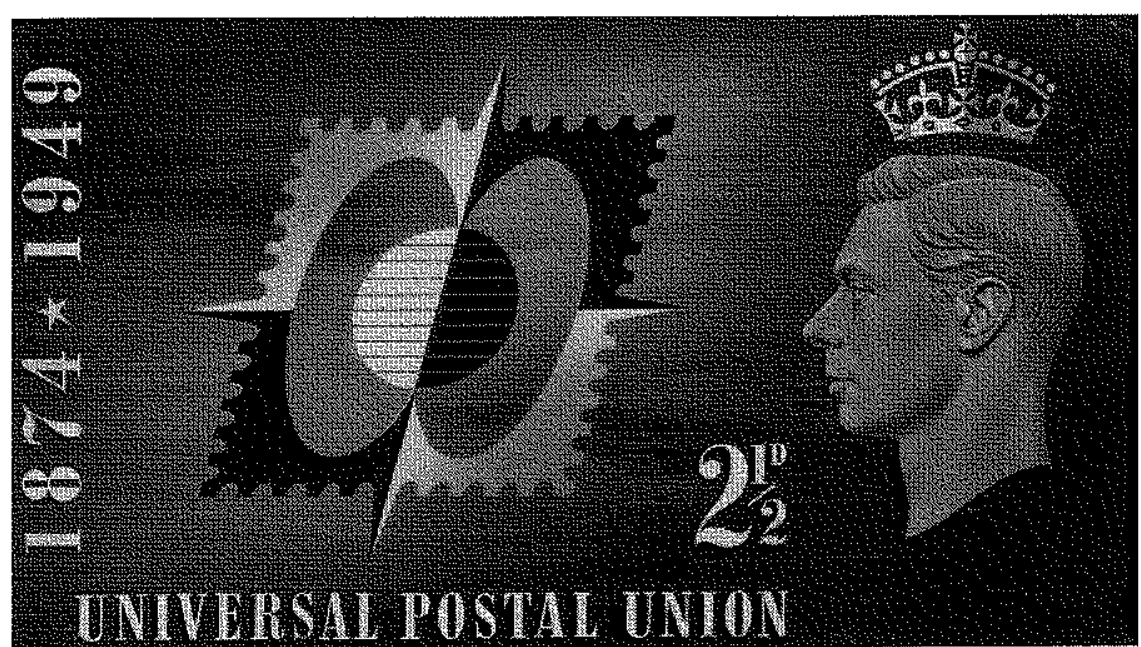

Figure 3.7 Unadopted design for a British postage stamp commemorating the 75 th anniversary of the Universal Postal Union.

Source: Postal Museum, London 


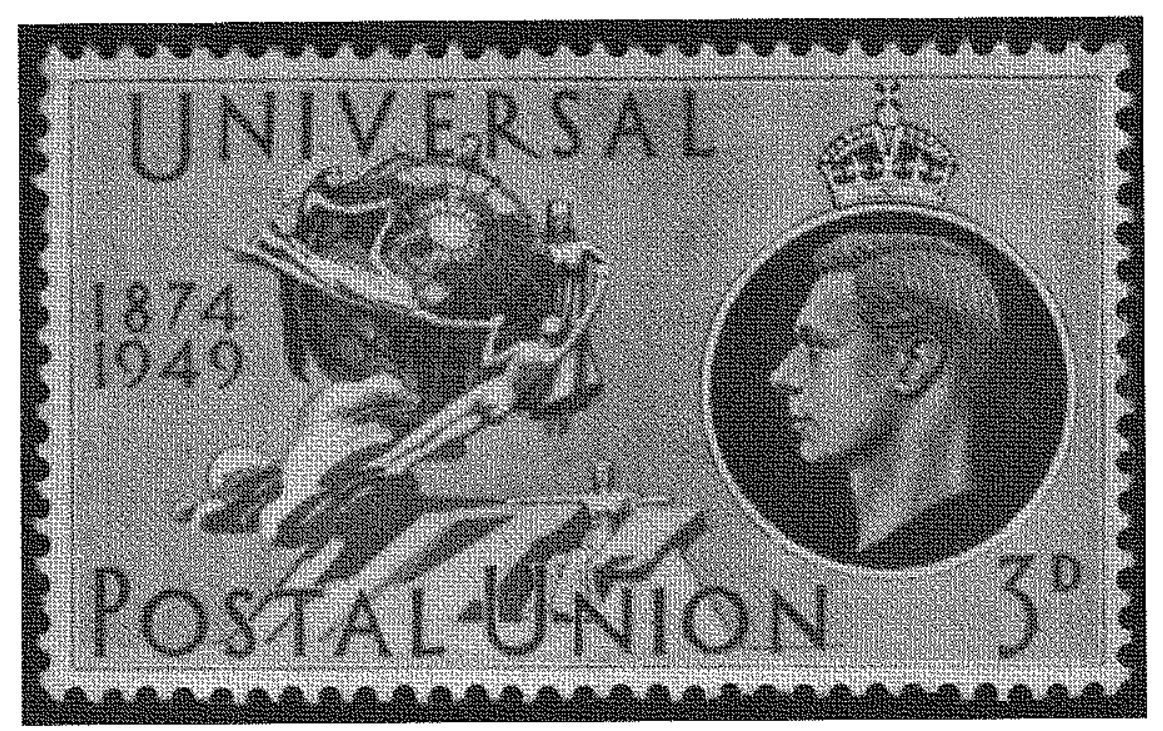

Figure 3.8 British postage stamp featuring art deco rendering of the Postal Union Monument in Berne.

Source: Robert Dalton Harris

design would feature only the five globe-encircling genii-typically without Saint-Marceaux's racialist stereotypes-and omit Berna altogether. This omission solved a practical problem: the monument's dual focus posed an obvious design challenge. Yet it almost certainly also reflected, especially for non-Europeans, a tacit decision to downplay the Postal Union's origins. By omitting Berna, these post-1949 stamp designers helped to transform a Eurocentric symbol moored in a specific city into a free-floating icon of a borderless world.

The four-stamp Crown Agency-designed Commonwealth commemoratives relied on a similar juxtaposition of the traditional and the modern. The lowest denomination featured the ancient messenger god Hermes and highly stylized evocations of present-day modes of postal transportation: the railroad, the steamship, the airplane. The other denominations featured, respectively, an old-fashioned paddle-wheel steamship and a modern airplane; Hermes scattering letters above the Atlantic Ocean; and the Postal Union monument in Berne. None were as backward looking as the Australian Postal Union commemorative, which juxtaposed a tiny airplane with an outsized rendering of a mounted post rider loping along in the outback, a throwback to an older, more insular parochialism that foregrounded the nation while downplaying the inclusivity of a borderless world.
The artful balancing of tradition and modernity served a pedagogical purpose. The Postal Union was 75 years old in 1949, while the Commonwealth was brand new. Though the strident Eurocentrism of the preSecond World War era was no longer in vogue, British publicists had not lost sight of geopolitics. In a fluid and uncertain age in which the British government confronted the challenges of decolonization and national selfdetermination, the facilities the Postal Union had long provided for safe, secure, and inexpensive international postal communications had now become a bulwark of stability. No longer did the inclusivity of the Postal Union challenge a pillar of British diplomacy. Imperialism and internationalism, it turned out, had more in common than prewar tatesmen had assumed.

Less stylistically novel than the British and Commonwealth commemoratives, yet more substantively innovative, was the three-stamp commemorative series that the U.S. Post Office Department issued to celebrate the Postal Union's 75th anniversary. None featured such familiar icons as steamships or railroads, even though each remained important modes of postal transportation. Rather, they accorded pride of place to airpower, a consummate symbol of technological modernity that melded together the national and the international in a manner reminiscent of the technocratic internationalism of the interwar period. ${ }^{87}$ The 10 -cent stamp (Figure 3.10) featured three postal icons in an awkward montage that the more aesthetically astute British stamp designers would almost certainly have rejected. The three icons were an airplane, the U.S. Post Office Department headquarters building in Washington, and the genii from the Postal Union monument. Each looked to the future: the headquarters building was recently completed; the airplane was a new mode of postal transportation; and the genii were no longer encumbered by the tradition-bound Berna. The 15 -cent stamp continued the transportation theme by featuring letter-bearing doves, while the 25 -cent stamp supplanted genii and doves with a vivid rendering of a globe-encircling state-of-the-art Boeing 377 Stratocruiser (Figure 3.9). By depicting on its highest-denomination stamp a U.S.-built airplane whose design had been modeled on a long-range bomber that the U.S. military had deployed extensively during the Second World War, the Post Office Department linked global communications with a technological icon closely connected to the emergence of the United States as a global superpower. ${ }^{88}$

If British postal administrators looked to the Postal Union to prop up the Commonwealth, their American counterparts regarded it as a showcase for a technically advanced "American Century." The American faith in progress was evident not only in the commemorative stamps the U.S. Post Office issued, but also in the souvenir envelopes philatelic dealers produced. British souvenir envelopes often included railroads and steamships to highlight the contrast between the old and the new. U.S. souvenir envelopes, in contrast, backdated U.S. involvement in the Postal Union and playę up 


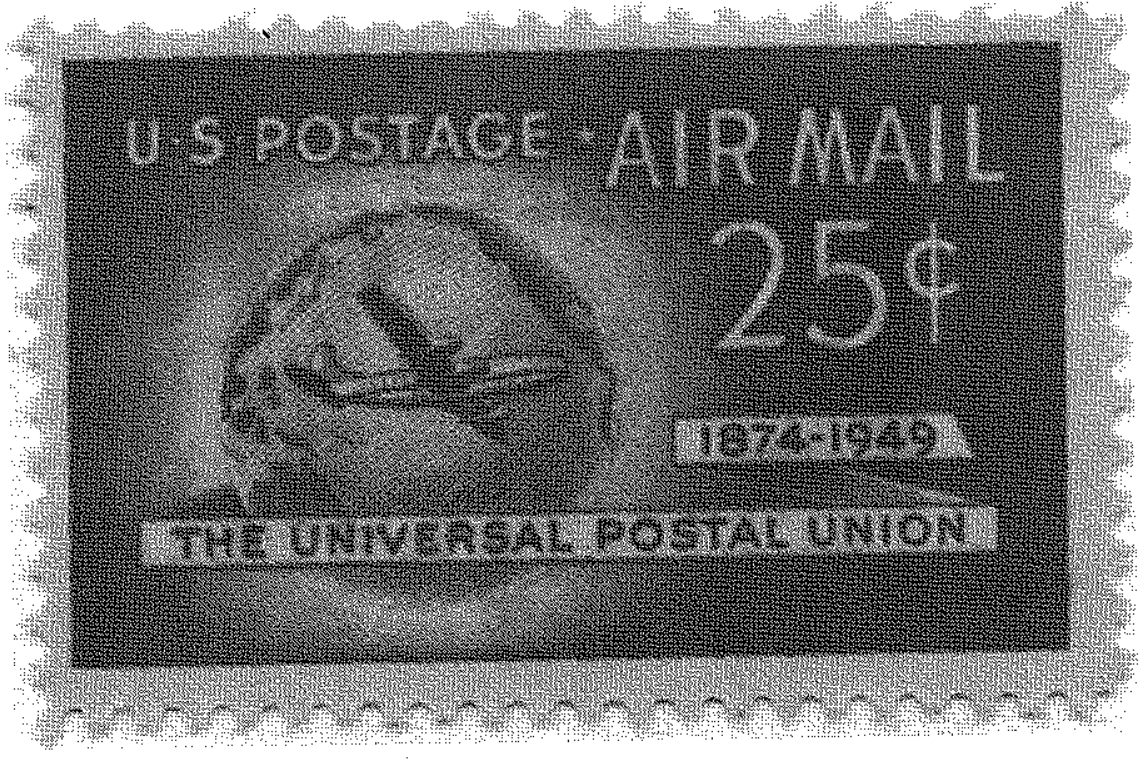

Figure 3.9 U.S. postage stamp commemorating the 75 th anniversary of the Universal Postal Union.

Source: Robert Dalton Harris

its modernity. No longer was it de rigueur to invoke mythological deities to symbolize the global flow of information. One envelope went so far as to juxtapose a profile of Montgomery Blair, the U.S. postmaster general who "proposed the first international postal congress," with Heinrich von Stephan, the "father of the Universal Postal Union." Others celebrated air power by depicting the exotic locales-Paris, Brazil, India-to which one could send a letter. One of the most intriguing recast the letter-carrying genii as a technical marvel, a self-propelled world-spanning ring of spinning letters that was automatically bringing the blessings of international communications to the people of the world (Figure 3.10). ${ }^{89}$ The proliferation of technocratic imagery illustrated the self-evident relationship that many Americans presumed to exist between technical advance and moral progress. This imagery, in turn, built on the sturdy Enlightenment conviction that the unimpeded circulation of information remained a uniquely powerful tool for hastening the modernization of the world. ${ }^{90}$

$$
* * *
$$

The 1949 commemoration of the Postal Union's 75 th anniversary brought the organization's formative era to a close. For many decades, the Postal

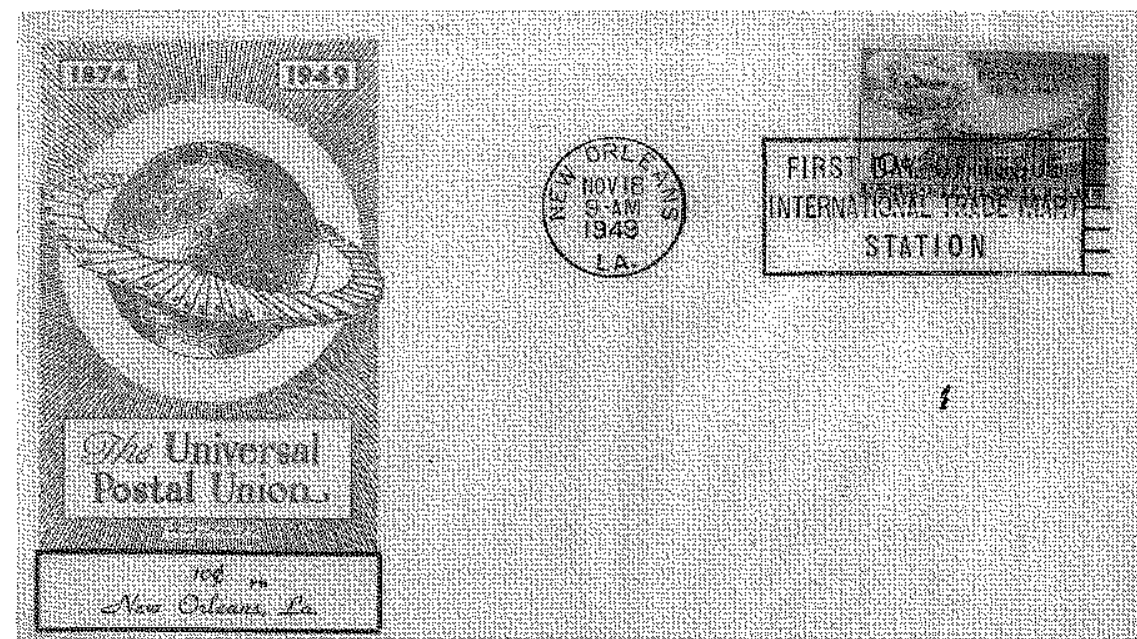

Figure 3.10 U.S. souvenir envelope celebrating the 75 th anniversary of the Universal Postal Union.

Source: author's collection

Union had operated in almost total obscurity. Now, in a turn of events that no one could have foreseen, its long record of achievement would help legitimate a new world order in which Germany had been crushed, the British Empire transmogrified into a Commonwealth, and the United States repositioned as a dominant player on the global stage. No postal congress convened in 1949. Yet if postage stamps can be taken as an expression of the zeitgeist, the Postal Union had finally lodged itself in the popular mind. "The postage stamp is, with the possible exception of its flag," declared the editor of the Jerusalem-based Palestine Post in 1940, "a nation's most important and widespread international symbol." Journalists discussed them, millions used them, and a large number of hobbyists mounted them in albums. In the case of the Postal Union, they provided some of the most evocative examples of its public image during its formative era.

If postage stamps-and, one might add, monuments, postcards, and souvenir envelopes-were important symbols, just what did they denote? In the case of the Postal Union, they revealed enduring tensions between invisibility and visibility, particularism and inclusivity, and the traditional and the modern.

These tensions surfaced in myriad ways. Not everything had worked out as its founders had hoped, as the editor of the Wellington, New Zealand, Evening Post reminded his readers in a thoughtful 1937 editorial: "The Victorian dream that freedom and ease of communications and intercourse 
between nations would produce friendship and cooperation has not exactly come true; there are other factors in the problem." Even so, the experts who ran the Postal Union were to be commended for the "professional pride" with which they had gone about their work, and deserved much credit for having demonstrated to a skeptical world that if the champions of international cooperation had the "common will" to work together, they could promote the public good..$^{92}$

The vast and sprawling global communications network that Postal Union administrators coordinated facilitated an unprecedented flow of information. Yet its mechanisms remained, and remain, opaque, and little discussed. To a large extent, this was by intention. For the leaders of many international organizations today-primed to regard lavish publicity as a sine qua non of success-this is startling and counterintuitive. The administrators who ran the Postal Union resisted the temptation to bask in the warm glow of publicity. By remaining in the shadows, they helped institutionalize the now-common presumption that-in international communications, to a greater degree than in perhaps any other realm-the particularism of locality, nation, and empire would eventually give way to the inclusivity of a borderless world.

\section{Acknowledgments}

For assistance in the preparation of this essay, I am grateful to Jonas Brendebach, Diane DeBlois, Richard Handler, Robert Dalton Harris, Martin Herzer, Nancy R. John, Ken P. Martin, Craig N. Murphy, José Rodriguez, Caroline Scannell, Heidi Tworek, and Dwayne Winseck. I owe special thanks to Leonard Laborie for the suggestion that Postal Union-related ephemera might prove insight into the organization's public image, and to Lukas Heim for gracious hospitality and expert research assistance in Berne. Thanks also to the Royal Mail Group Limited for permission to reproduce images of stamps and unadopted stamp designs.

\section{Notes}

1 H. G. Wells, The New World Order: Whether it is Attainable, How It Can Be Attained, and What Sort of World a World at Peace Will Have to Be (New York: Alfred A. Knopf, 1940), 118-119.

2 The distinction between the Postal Union and a treaty-making body-and, more basically, between technical administration and international diplomacy-is explored in D. Howland, "Japan and the Universal Postal Union: An Alternaexplored in D. Howland, "Japan and the Universal Postal Union: An Alterna17 (2014): 23-29. Unlike pre-Postal Union champions of ocean penny postage, Howland observed, Postal Union administrators looked forward not to eterna peace but, instead, to the "practical realization" that the "mutual advantages to be secured by their common interest justified some collective administration of their mutual activities" (p. 23). For a related discussion, see D. Howland "An Al heir mu in the Nineteenth Century," Review of International Studies 41 (2015): 161-183; L. Laborie, L'Europe mise en réseaux: La France et la coopération internationale dans les postes et les télécommunications, années 1850-années 1950 (Brussels: Peter Lang, 2010); D. Vincent, "The Progress of Literacy," Victorian Studies 45 (2003): 406-409; M. Geyer and J. Paulmann, ed., The Mechanics of Internationalism: Culture, Society, and Politics from the 1840 s to the First World War (New York: Oxford University Press, 2001) and "The Governance of International Communications: Business, Politics, and Standard-Setting in the Nineteenth and Twentieth Centuries," Special Issue of the Journal of Policy History 27, no. 3 (2015)

3 C.S. Maier, Once Within Borders: Territories of Power, Wealth, and Belonging since 1500 (Cambridge, MA: Harvard University Press, 2016), ch. 5.

$4 \mathrm{M}$. Koskenniemi, The Gentle Civilizer of Nations: The Rise and Fall of International Law, 1870-1960 (Cambridge: Cambridge University Press, 2001), D.R. Winseck and R.M. Pike, Communication and Empire: Media, Markets, and Globalization, 1860-1930 (Durham, NC: Duke University Press, 2007).

5 R.R. John, "Protecting Power Overseas: U.S. Postal Policy and International Standard-Setting at the 1863 Paris Postal Conference," Journal of Policy History $27(2015): 416-438$

6 L'Union postal universelle sa fondation et son développement, 1874-1949mémoire (Berne: Union postale universelle, 1949), 100, 248.

7 On the limits of the telegraph as a popular medium, see S.M. Müller, "Beyond the Means of 99 Percent of the Population: Business Interests, State Intervention, and Submarine Telegraphy," Journal of Policy History 27 (2015): 439-464, and R. R. John, Network Nation: Inventing American Telecommunications (Cambridge, MA: Harvard University Press, 2010), chs. 4-5.

8 The phrase "Victorian Internet" was popularized in 1998 by British journalist Tom Standage in a popular history of the electric telegraph. By linking the Internet and the telegraph, Standage fostered the misleading assumption that the social effects of the two media were analogous. In fact, the nineteenth-century telegraph remained a niche medium for an exclusive clientele that was little used by the vast majority of the population.

9 "Kasson's Good Idea," Abbeville, South Carolina Press and Banner, September 4 1895.

10 "Stead Sees Dawn of World's Unification," Chicago Examiner, August 14, 1910.

11 "Nature and Operation of International Law," Baltimore Sun, May 30, 1924.

12 "The Postal Union," Sydney Morning Herald, July 18, 1929.

13 L. Woolf, International Government (London: George Allen \& Unwin, 1916), 197.

14 The cultural significance of postcards, souvenir envelopes, postage stamps, and other kinds of ephemera is a neglected topic. For an introduction, see K. Jeffrey, "Crown, Communication and the Colonial Post: Stamps, the Monarchy, and the British Empire," Journal of Imperial and Commonwealth History 34 (2006) $45-70$.

15 G.A. Codding, Jr., The Universal Postal Union (New York: New York University Press, 1964), 39-42, 55-61; Diane DeBlois, "Kinderpost as Teaching Aid," Postal History Journal $130(2005): 6$.

16 "The Color of Stamps," Indiana Farmer's Journal, December 11, 1920; "Postal Union Jubilee," The Times, July 21, 1924; "Universal Postal Union Has Been the World's Most Efficient Mailman for 67 Years," New York Herald Tribune, June 15, 1941. 
66 Richard R. Jobn

17 For more on Burritt and the pre-Postal Union movement to reduce and simplify international postal rates, see P.A. Shulman, "Ben Franklin's Ghost: World Peace, American Slavery, and the Global Politics of Information before the UniPeace, American Slavery, and of Global History 10, no. 2 (2015): 212-234.

18 André-Adolphe-Eugène Disdéri, "Conferénce de Paris 1863," in L'Union postal universelle mémoire 15. Disdéri produced at least two versions of this carte universelle... mémoire, 15. Disdéri produced at least two verslace and Blair is de visite. In this second version, Vandal is accorded pride-of-place and Blair is nowhere to be found. Disdéri, "Mosaïque," at Paul Frecker, "Nineteenth-Century Photography," retrieved from www.paulfrecker.com/pictureDetails.cfm?pagety pe=library\&typeID=22\&ID=5398 (accessed October 22, 2017)

19 John, "Projecting Power Overseas;" R. R. John, "The Political Economy of Postal Jing nology $55(2010): 3-12$.

20 'Kasson's Good Idea," Abbeville, South Carolina, Press and Banner, September 4, 1895.

21 L'Union postal universelle ... memoire, 53, 89, 105

22 The characterization of landmark anniversaries as "jubilees" was a fin de siècle innovation that has been aptly termed an "invented tradition." $\mathrm{E}$. Hobsbawm innovation that has brion versity Press, 1983), 281.

3 Codding, Universal Postal Union, 154, 251

4 R. Münger, "Vingt cinquième anniversaire de la fondation de l'Union Postale Universelle Berne, 1875-1900," postcard, Berne: Lips, 1900. I am grateful to José Rodriguez for assistance in identifying this item.

25 R. Münger diary, May 22, 23; June 2, 11; July 9, 27, 28, 30, Münger papers, Burgerbibliothek, Berne, Switzerland; R Münger, "Vingt cinquieme anniverBurgerbibliothek, Berne, S'Union Postale Universelle Berne, 1875-1900," invitasaire de la fondation de l'0 nion P_Vers-099 A 0019-3, Swiss PTT Archive and tion, Berne: Lips, 1900, P-00

"Library, Berne, Switzerland.

26 "The festivities of the Universal Postal Union," L'Union Postale $25(1900): 163$ "Competition for the Erection of a Monument in Commemoration of the Foundation of the Universal Postal Union," L'Union Postale 25 (1902): 189 . Though the German government offered to contribute 200,000 francs to the project, Postal Union administrators decided to fund the monument out

tion's "ordinary expense." "Festivities," LUnion Postale, 163.

27 "Competition for the Erection of a Monument in Commente dation of the Universal Postal Union," L'Union Postale 29 (1904). 139; "Inauguration of the Monument Commemorative of the Foundation of the Universal Postal Union," L'Union Postale 34 (1909): 113.

28 P. Chevalier, "Old-World Chitchat," Cincinnati Enquirer, 28 May 1908; Mark H. Chevalier, Old-W on Wrinceton, NJ: PrinceMazower, Governing the World: The

ton University Press, 2012), 113-114.

29 The 1946 Guatemala commemorative omitted Berna, a harbinger of things to come. For help in identifying occurrences of the

postage stamps, I am grateful to Caroline Scannell.

30 "The Postal History of ICAOPCAlHistory/icao_and_the_universal_postal_union. from www.icao.int/secretariat/Post January 11, 2017).

htm (accessed January 11, 2017).

1 “Festivities," L'Union Postale, 161; "Unveiling of the Monument Contale 34 orating the Fou

"The Washington Postal Congress," L'Union Postale 22 (1897): 134; "The

Universal Postal Congress of Rome," L'Union Postale 31 (1906): 119; "Unveiling," L'Union Postale, 169-170, 178.
33 Codding, Universal Postal Union, 38.

34 "Festivities," L'Union Postale, 163; "Unveiling," L'Union Postale, 166.

35 "Unveiling of the Monument Commemorating the Foundation of the Universal Postal Union," American Journal of International Law 4 (1910): 185-186.

36 "Unveiling," L'Union Postale, 162.

37 A copy of Saint-Marceaux's original maquette-sans Berna-can be found among the collections of the Swiss Museum of Communication in Berne.

38 Gabriele Balbi, Simone Fari, Giuseppe Richeri, and Spartaco Calvo, Network Neutrality: Switzerland's Role in the Genesis of the Telegraph Union, 1855-1875 (Berne: Peter Lang, 2014), chaps. 1-3.

39 "Unveiling," American Journal of International Law.

40 "Postal Union Symbolized," New York Times, March 29, 1908.

41 Marietta Rohner, "Das Weitpostdenkmal in Bern," M.A. thesis Berne University, 1992, 55-58.

42 Chevalier, "Old-World Chitchat."

43 "Unveiling," American Journal of International Law, 185-186.

44 E. Hayes "Education and World Peace" Intercollegiate Socialist 2 (1915). Interestingly, the same issue of the Intercollegiate Socialist in which Hayes's article appeared included an early syllabus for a university course in international relations. I am grateful to Craig N. Murphy for this citation.

45 "The Parliament of the Post," The Guardian, October 1, 1920.

46 "Unveiling," L'Union Postale, 161.

47 "Unveiling," L'Union Postale, 176.

48 Howland, "Alternative Mode," 161-173.

49 Howland, "Japan and the Universal Postal Union," 33. Imperial politics complicated voting procedures at the Postal Union. In the late nineteenth century, the British Empire had three votes: one for the United Kingdom, one for British India, and one for Britain's other colonies. At the 1929 London congress, 50 British colonies shared a single vote. Britain's situation was not unique. In that year, nine countries had colonial votes: Belgium, France, Italy, Japan, the Netherlands, Portugal, Spain, the United Kingdom, and the United States. How their history has yet to be written. Howland, "Alternative Mode," 173.

50 F.H. Williamson, "The International Postal Service and the Universal Postal Union," Journal of the Royal Institute of International Affairs 9 (1930): 71-72. 1 Ibid., 68.

52 The Postal Union convened twelve congresses between 1874 and 1949: 1874 (Berne); 1878 (Paris); 1885 (Lisbon); 1891 (Vienna); 1897 (Washington); 1906 (Rome); 1920 (Madrid); 1924 (Stockholm); 1929 (London); 1934 (Cairo); 1939 (Buenos Aires); 1947 (Paris). Its executive committee also convened periodically in different countries: in 1933, for example, it met in Ottawa, Canada. How the Postal Union decided where to meet is an open question. Much pre sumably depended on the willingness of the host city to cover the associated costs, in return for which it hoped to reap some kind of public relations benefit. For a related discussion, see H. Tworek, "The Creation of European News: News Agency Cooperation in Interwar Europe," Journalism Studies 14, no. 5 (2013): 730-742.

53 "World's Postoffice," Milwaukee Sentinel, February 7, 1897.

54 "Mail of All the Globe," Macon, Georgia, Telegraph, May 3, 1897

55 "Postal Union Meets," Milwaukee Journal, May 5, 1897

56 "World's Postoffice," Milwaukee Sentinel, February 7, 1897.

57 "Fifth World Congress for Cheap Postage," San Francisco Chronicle, April 18, 1897.

58 "A Great Postal Congress," Boston Daily Globe, April 26, 1897. 
59 "Friendly Ties," Boston Journal, May 5, 1897.

60 "The Postal Congress and Internationalism," Minneapolis Journal, June 16, 1897.

61 "The Postal Congress," Seattle Post-Intelligencer, May 5, 1897. See also "Universal Postal Union," Topeka, Kansas, Advocate, May 12, 1897.

62 R.M. Pike, "National Interest and Imperial Yearnings: Empire Communications and Canada's Role in Establishing the Imperial Penny Post," Journal of Imperial and Commonwealth History 26 (1998): 34-41; G. B. Artken, Canada and the Universal Postal Union (Toronto: Unitrade Press, 1992), 32.

63 For an analogous controversy in the realm of international property rights that had a different outcome, see L. Bently, "Copyright, Translations, and Relations between Britain and India in the Nineteenth and Early Twentieth Centuries," Chicago-Kent Law Review 82 (2007): 1181-1240.

64 Universal Postal Congress, presentation envelope, "One Set of Specimens," retrieved from http://arago.si.edu/record_149198_img_1.html (accessed November 2, 2016).

65 New York postmaster, "To Their Colleagues in the Universal Postal Union ... A Happy New Year," New York: Post Office Department, 1892. The postcard's design included several features that would recur in Postal Union-themed imagery: the rendering of the globe as two hemispheres and a scattering of letters addressed to different countries.

66 L. Laborie, "Global Commerce in Small Boxes: Parcel Post, 1878-1913," Journal of Global History 10, no. 2 (2015): 235-258.

67 "Postal Progress in the World," Boston Daily Globe, March 21, 1904.

68 "International Postage," Baltimore Sun, November 30, 1904.

69 Laborie, "Global Commerce;" R. R. John, ed., The American Postal Network, 1792-1914, vol. 4 (London: Pickering \& Chatto, 2012), 225-252.

70 F.H. Williamson, "The Universal Post," The Times, May 10, 1929.

71 Williamson, "International Postal Service," 78. English would not become an official language of the Universal Postal Union until 1994.

72 "Universal Postal Union," The Times, May 11, 1929.

73 Derby [Ireland] Daily Telegraph, May 10, 1929.

74 Williamson, "International Postal Service," 68-78.

75 Ibid.

76 Exeter and Plymouth Gazette, May 21, 1929.

77 "International Telegraph Conference (London, 1903)," retrieved from www. itu.int/en/history/Pages/TelegraphAndTelephoneConferences. aspx? $\operatorname{conf}=4.24$ (accessed January 11, 2017).

78 Universal Postal Union notepaper, presentation sheet, London 1929, retrieved from https://en.wikipedia.org/wiki/Postal_Union_Congress_\%C2\%A31_stamp (accessed November 2, 2016).

79 "The Postal Union," Sydney Morning Herald, July 18, 1929.

$80 \mathrm{H}$. Nelson, rejected design for stamp commemorating the 1924 British Empire Exhibition, Postal Museum, London, retrieved from http:/postalmuseum.org/ discover/collections/philatelic-collection/british-stamps/george-v-stamps/britishempire-exhibition (accessed November 2, 2016).

81 E.M. Jackson, rejected design for stamp commemorating the 1929 London Postal Union Congress, Postal Museum, London, retrieved from http://postal museum.org/discover/collections/philatelic-collection/british-stamps/george-vstamps/postal-union-congress (accessed November 2, 2016).

82 M. Gill, Mail Steamship Routes (London: General Post Office, 1937).

83 K. B. Stiles, "News of the World of Stamps," New York Times, August 29, 1949.

84 Daniel Gorman, Imperial Citizenship and the Question of Belonging (Manchester: Manchester University Press, 2007).
85 A. Games, rejected design for stamp commemorating the Postal Union's 75th anniversary, Postal Museum, London, retrieved from https:/postalheritage.files. wordpress.com/2015/09/gvi-121-018.jpg (accessed November 2, 2016)

86 B. Hughes-Stanton, rejected design for stamp commemorating the Postal Union's 75 th anniversary, Postal Museum, London, retrieved from http://cdn.collections base.org.uk/gb813/GVI-13L-019.jpg (accessed November 2, 2016).

87 On "technocratic internationalism," see Johan Schot and Vincent Lagendijk, "Technocratic Internationalism in the Interwar Years: Building Europe on Motorways and Electric Networks," Journal of Modern European History 6, no. 2 (2008): 197-199. For a transatlantic perspective, see Thomas P. Hughes, American Genesis: A History of the American Genius for Invention (New York: American Genesis: A Histo

88 Jenifer Van Vleck, Empire of the Air: Aviation of the American Astendancy (Cambridge, MA: Harvard University Press, 2013), ch. 5.

89 "Constitution of the Union," souvenir envelope, 1949; R. McCawley, "Universal Postal Union, 1874-1949," souvenir envelope, 1949; both in author's possession.

90 For a related discussion, see Margaret A. Blanchard, Exporting the First Amendment: The Press-Government Crusade of 1945-1952 (White Plains, NY: Longman, 1986); Frank Beyersdorf, "The 'United Nations Ideal' in War and Peace: Strategies of International Information Policy in the 1940s," unpublished manuscript in author's possession; and Lee Bollinger, Uninbibited, Robust, and WideOpen: A Free Press for a New Century (New York: Oxford University Press, 2010).

91 "Britain Celebrates the Centenary of the Postage Stamp," Palestine Post [Jerusalem], May 7, 1940.

92 "The Postal Union," Wellington, New Zealand, Evening Post, January 14, 1937. 